\title{
Invasive aspergillosis successfully treated by combined antifungal therapy and immunosuppressive monotherapy two months following heart transplantation
}

\author{
Tomasz Urbanowicz ${ }^{1}$, Bartłomiej Żabicki², Hanna Baszyńska-Wachowiak³ ${ }^{3}$ Ewa Straburzyńska-Migaj ${ }^{3}$, \\ Robert Juszkat $^{2}$, Stefan Grajek ${ }^{3}$, Marek Jemielity ${ }^{1}$ \\ ${ }^{1}$ Cardiac Surgery and Transplantology Department, Chair of Cardio-Thoracic Surgery, Poznan University of Medical Sciences, \\ Poznan, Poland \\ ${ }^{2}$ Radiology Department, Poznan University of Medical Sciences, Poznan, Poland \\ ${ }^{3}$ Cardiology Department, Poznan University of Medical Sciences, Poznan, Poland
}

Kardiochirurgia i Torakochirurgia Polska 2016; 13 (2): 164-168

\begin{abstract}
Invasive aspergillosis is becoming increasingly prevalent, especially following transplantation. Invasive aspergillosis is associated with mortality. Successful therapy is related to early diagnosis and proper therapy. We present the case of a 61-year-old man suffering from invasive aspergillosis 2 months following heart transplantation. He was suffering from hypertrophic cardiomyopathy and he underwent orthotropic heart transplantation. He was readmitted to the Department of Cardiology 69 days following transplantation due to symptoms of productive cough for 5 days. It was accompanied by chest pain, shortness of breath, and fever up to $39^{\circ} \mathrm{C}$. He was slightly cyanotic and confused on physical examination. The patient's status deteriorated within the following 2 days. On bronchoscopic specimen examinations Aspergillus mould filaments were detected and the serum galactomannan index was 12.162 . His blood saturation decreased to $85 \%$. C-reactive protein serum level increased to $273 \mathrm{mg} / \mathrm{l}$. The patient was admitted to the intensive care unit and intubated due to severe respiratory insufficiency. Computed tomography revealed massive, mostly homogeneous consolidation. The patient was treated with $200 \mathrm{mg}$ of voriconazole and $50 \mathrm{mg}$ of caspofungin daily. Caspofungin therapy was continued for 23 days and voriconazole was administered parenterally for 62 days. Voriconazole therapy was continued orally for 9 months. During combined antifungal therapy, the galactomannan serum index constantly decreased from 12.1 to 0.33 (end-point of caspofungin therapy) and to 0.23 (end-point of voriconazole parenteral administration). His immunosuppressive therapy was limited to calcineurin inhibitor (tacrolimus) monotherapy. Post-treatment imaging 9 months after diagnosis confirmed the efficacy of therapy as a lack of pulmonary infiltration associated with left apical peribronchial scarring as a result of treatment. The
\end{abstract}

\section{Streszczenie}

Grzybica kropidlakowa płuc, zwykle wywołana przez grzyby z rodzaju Aspergillus, stanowi najczęstszą postać inwazyjnej grzybicy układu oddechowego po operacji transplantacji serca. Zakażenie płuc tym patogenem, nierozpoznane we wczesnym stadium lub nieskutecznie leczone, wiąże się z ryzykiem wystąpienia powikłań śmiertelnych. Przedstawiamy przypadek 61-letniego chorego z rozpoznaniem aspergillozy płuc w ciągu 2 miesięcy od zabiegu ortotopowego przeszczepu serca. Pacjenta poddano operacji z powodu niewydolności krążenia wtórnej do kardiomiopatii przerostowej. Chory został przyjęty w trybie pilnym, początkowo, na oddział kardiologii, w 69. dniu po procedurze podstawowej, z objawami duszności i kaszlu trwającego od 5 dni. Towarzyszyły mu ból w klatce, zasinienie powłok skórnych, zaburzenia świadomości i temperatura ciała $39^{\circ} \mathrm{C}$. Stan chorego uległ stopniowemu pogorszeniu w czasie kolejnych 2 dni. Wynik wykonanego badania mikrobiologicznego uzyskanego podczas bronchoskopii drzewa oskrzelowego potwierdził obecność strzępek grzyba, a stężenie galaktomannanu oszacowano na poziomie wartości 12,162. Podczas hospitalizacji obserwowano wzrost poziomu białka C-reaktywnego w surowicy do $273 \mathrm{mg} / \mathrm{l}$ oraz spadek stopnia saturacji krwi do $85 \%$. Pacjent został przyjęty na oddział intensywnej terapii oraz wymagał wentylacji mechanicznej. W badaniu tomografii komputerowej klatki piersiowej rozpoznano masywne zagęszczenia miąższu płucnego. Rozpoczęto terapię przeciwgrzybiczą skojarzoną z $200 \mathrm{mg} /$ dobę worikonazolu oraz 50 mg/dobę kaspofunginy. Terapię za pomocą kaspofunginy kontynuowano przez okres 23 dni, a worikonazolu przez 9 miesięcy, obejmujący 62 dni terapii parenteralnej. W trakcie leczenia indeks galaktomannanu zmniejszyt się z wartości 12,1 do 0,33 (na końcu terapii kaspofunginą), a następnie do 0,23 (koniec podań dożylnych worikonazolu).

Address for correspondence: Tomasz Urbanowicz MD, PhD, Cardiac Surgery and Transplantology Department, Poznan University of Medical Sciences, 1/2 Długa St, 61-848 Poznan, Poland, phone: + 48605552 551, fax: +48 6185490 85, e-mail: tomasz.urbanowicz@skpp.edu.pl 
present case proved the efficiency of combined (voriconazole and caspofungin) antibiotic therapy in invasive pulmonary aspergillosis. Computed tomography findings followed by the serum galactomannan index are useful tools for early diagnosis. Additional modification of the immunosuppressive regimen can be performed safely in the early postoperative period in case of severe infection.

Key words: heart transplantation, aspergillosis, fungal infection.

\section{Introduction}

Invasive aspergillosis is becoming increasingly prevalent, especially following transplantation. The incidence of invasive fungal infections following solid organ transplantation varies from $1.4 \%$ to $42 \%$ [1]. Invasive pulmonary aspergillosis (IPA) is a more common etiology of fungal infections in heart transplantation recipients than candidiasis [2]. Although there are advances in therapeutic and diagnostic possibilities, invasive aspergillosis is associated with as high as 60-85\% mortality rate [3-6]. Successful therapy is related to early diagnosis that usually relies on culture and computed tomography (CT) findings [7].

We present the case of a 61-year-old man suffering from invasive aspergillosis two months following heart transplantation.

\section{Case report}

He was suffering from hypertrophic cardiomyopathy and he underwent orthotropic heart transplantation with the lower Shumway technique. He was awaiting urgent heart transplantation due to repetitive pulmonary edema episodes despite inotropic support. Cold ischemia time was 216 minutes, and cross clamping time was 142 minutes. Induction therapy including basiliximab was applied. The postoperative period was complicated by pericardial effusion treated by surgical drainage on the $12^{\text {th }}$ day. Decubitus ulcers of both heels were noted during intensive care unit stay and they required surgical interventions. He stayed 41 days in the intensive care unit and overall postprocedural hospitalization time was 53 days.

Postoperative echocardiography was satisfactory, with left ventricle ejection fraction of $73 \%$ and intraventricular septum diameter below $12 \mathrm{~mm}$. Routine blood tests on discharge revealed normal white blood count $\left(5 \times 10^{9} / \mathrm{l}\right)$, hemoglobin concentration $(7.3 \mathrm{mmol} / \mathrm{l})$ and platelet count $\left(367 \times 10^{3} / \mathrm{l}\right)$. Protocol endomyocardial biopsies performed on the $8^{\text {th }}, 23^{\text {rd }}$ and $38^{\text {th }}$ day were negative for rejection (grade 0 according to International Society for Heart and Lung Transplantation criteria). He was discharged on triple standard immunosuppressive therapy including tacrolimus (serum concentration $11 \mathrm{mg} / \mathrm{l}$ ), mycophenolate mofetil (serum concentration $2 \mathrm{mg} / \mathrm{l}$ ) and prednisolone (20 mg daily). An early marker of cytomegalovirus infection (pp65) was negative throughout the hospitalization.

He was readmitted to the Department of Cardiology at 69 days following transplantation due to complaints of pro-
Immunoterapia chorego podczas hospitalizacji została ograniczona do monoterapii inhibitorem kalcyneuryny (takrolimus). Kontrolne badanie tomografii komputerowej wykonane po zakończeniu terapii potwierdziło skuteczność podwójnej terapii przeciwgrzybiczej z resztkowymi obszarami zbliznowacenia.

Słowa kluczowe: transplantacja serca, Aspergillus, kropidlak, grzybica płuc.

ductive cough for 5 days. It was accompanied by chest pain, shortness of breath, and fever up to $39^{\circ} \mathrm{C}$. He was slightly cyanotic and confused on physical examination.

A routine blood test showed no pathological results except leucopenia $\left(3.4 \times 10^{9} / \mathrm{l}\right)$ and an increased level of the inflammatory marker C-reactive protein $(43.8 \mathrm{mg} / \mathrm{l})$. Blood saturation was $92 \%$ and chest $X$-ray revealed hypodense masses on the side of the left lung. Serum galactomannan index as part of a routine procedure following transplantation was measured.

Antibiotic therapy including parenteral infusion of piperacillin $4.0 \mathrm{~g}$ and tazobactam $0.5 \mathrm{~g}$ three times a day was started. Bronchoscopy was performed and specimens for microbiology examinations were taken.

The patient's status deteriorated within the following two days. On bronchoscopic specimen examinations Aspergillus mould filaments were detected and the serum galactomannan index was 12.162. His blood saturation decreased to $85 \%$. The C-reactive protein serum level increased to $273 \mathrm{mg} / \mathrm{l}$.

The patient was admitted to the intensive care unit and intubated due to severe respiratory insufficiency. Computed tomography $(\mathrm{CT})$ revealed massive, mostly homogeneous consolidation of left apical segments and patchy infiltration in the right lung. Additionally, bilateral pleural effusion with associated left-sided basal atelectasis was detected (Fig. 1). Computed tomography findings accompanied by laboratory tests and culture confirmed the diagnosis of invasive aspergillosis. The consolidation pattern did not strictly fulfill a certain type of IPA. Peribronchial consolidation and small airway lesions typical for airway invasive pattern were combined with typical internal low attenuation zones and a discrete halo sign related to the angioinvasive form. No typical signs for infarct shaped consolidation and no air crescent sign were detected.

The patient was treated with $200 \mathrm{mg}$ of voriconazole and $50 \mathrm{mg}$ of caspofungin daily. The decision to use a combination of both drugs was based on the severity of fungal invasion. He was extubated on the $8^{\text {th }}$ day following admission. Caspofungin therapy was continued for 23 days and voriconazole was administered parenterally for 62 days. Voriconazole therapy was continued orally for 9 months. During combined antifungal therapy, the galactomannan serum index constantly decreased from 12.1 to 0.33 (endpoint of caspofungin therapy) and to 0.23 (end-point of voriconazole parenteral administration). 


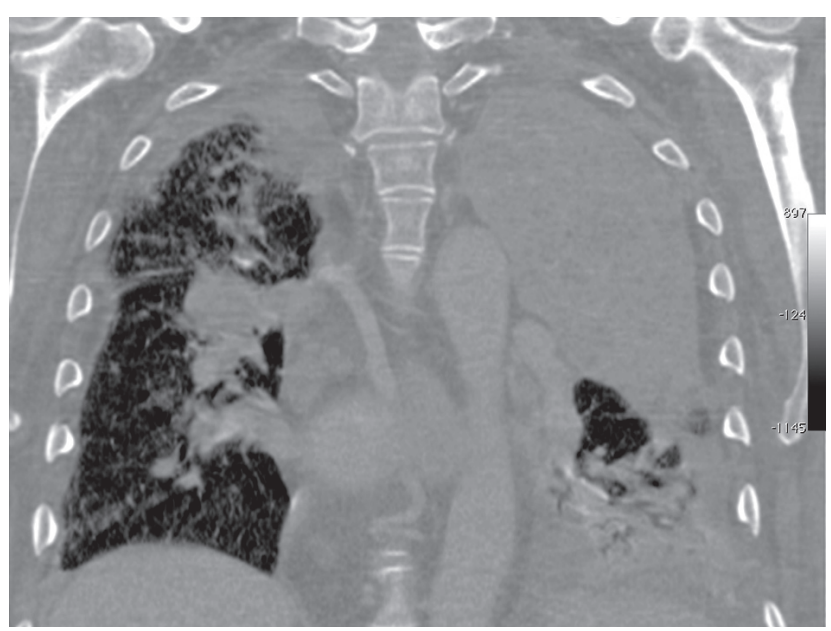

Fig. 1. Computed tomography scan prior to therapy, revealing invasive aspergillosis. Axial and coronal maximum intensity projection (MIP) images - massive mostly homogeneous consolidation of left apical segments and patchy infiltration in right lung. Additionally bilateral pleural effusion with atelectasis in left basal segments

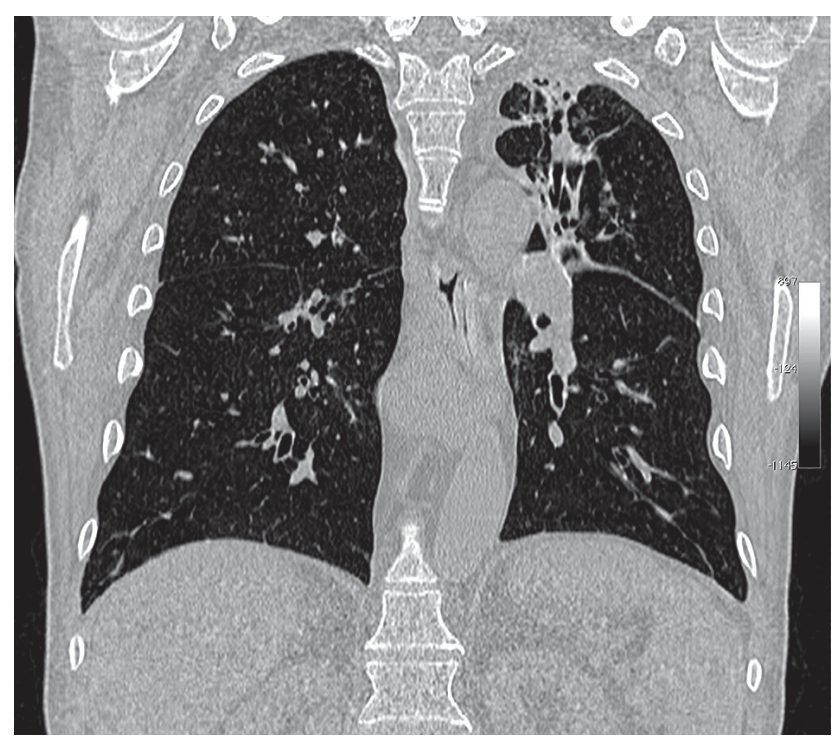

Fig. 2. Computed tomography scan following antifungal therapy. Follow-up 9 months after initial CT imaging. Scans at the corresponding level reveal no retaining infiltration. Remaining peribronchial scarring in left apical segments as a result of treatment

His immunosuppressive therapy was limited to calcineurin inhibitor (tacrolimus) monotherapy. Steroids and antiproliferative mycophenolate mofetil were withdrawn due to severe infection. Calcineurin inhibitor serum concentration was at therapeutic levels (mean $12 \pm 2 \mathrm{mg} / \mathrm{l}$ ).

Follow-up CT imaging on a regular schedule presented continuous regression of pulmonary lesions. Post-treatment imaging 9 months after diagnosis confirmed the efficacy of therapy as a lack of pulmonary infiltration associated with left apical peribronchial scarring as a result of treatment (Fig. 2).

\section{Discussion}

There is a high percentage (up to 40\%) of Aspergillus lung colonization in the general population [8]. In immunocompetent organisms antifungal defensive protection includes mechanical barriers, phagocyte activation and antimicrobial peptide release. The airways are the most frequent ports for invasion, especially in immunocompromised patients and especially following transplantation. The other predisposing risk factors for developing invasive aspergillosis that have been reported include severe and prolonged neutropenia, allogeneic stem cell transplantation, and prolonged use of corticosteroids $[9,10]$. The etiology of this fungal infection in heart transplantation recipients is more frequently aspergillosis than candidiasis.

Invasive pulmonary aspergillosis in immunocompromised patients can be classified into two different patterns based on CT imaging pattern. Aspergillus may invade blood vessels, causing hemorrhagic infarction that is called angio-invasive aspergillosis. It can cause tracheobronchitis, bronchiolitis or pneumonia, being classified as airway-invasive aspergillosis. Each of the types has a distinct histologic pattern and CT appearance [11]. Computed tomography is one of the essential examinations performed for noninvasive diagnosis of fungal infection. An angio-invasive pattern typically comprises an infarct-shaped consolidation, a halo sign and an internal low attenuation, cavity or crescent sign. Small airway lesions as small, clustered or centrilobular micronodules and branching linear opacities, a peribronchial consolidation and a bronchiectasis support the diagnosis of an airway-invasive form [12-14].

Successful therapy is related to early diagnosis that usually relies not only on computed tomography findings. Apart from imaging tools, microbiology and histopathology diagnostics are necessary. Instead of microbiology culture, a serum Aspergillus antigen named galactomannan has been reported as a reliable test for detecting invasive aspergillosis $[15,16]$. By using galactomannan (GM), a prompt diagnosis can be established a few days earlier compared to other methods [17] The galactomannan index can be determined in serum and BAL samples. Although some residual GM might still be present in piperacillin/tazobactam, currently available brand piperacillin/tazobactam preparations seem no longer responsible for false-positive GM results [18]. The patient was treated with piperacillin/tazobactam prior to galactomannan examination in the present study.

The combination of both antifungal drugs - voriconazole and caspofungin - was reported to have better results than caspofungin monotherapy. Azoles target the fungal cell membrane and echinocandins act on the cell wall. Voriconazole monotherapy is claimed to be associated with lower Aspergillus-related mortality compared to caspofungin alone [19]. Caspofungin is approved for therapy in patients who experience failure with other antifungal drugs $[20,21]$.

The gold standard in diagnosis of Aspergillus infection is histopathological examination of pulmonary lung tissue 
$[22,23]$. Such examination allows for the exclusion of malignancy or non-fungal infectious diseases. Histopathological examination is not only invasive but also requires time to obtain a proper diagnosis. In acute pulmonary insufficiencies, as presented in our study, noninvasive diagnostic tools (computed tomography and serum galactomannan index) are the best options.

Surgical resection is one of the possible therapeutic interventions, too [24-27]. It may prevent further aspergillosis spread to other organs. Indications for resection are limited to hemoptysis, pulmonary lesions that are contiguous with major blood vessels or pericardium and chest wall invasion. The safety of surgical resection in immunocompromised patients has been reported [28]. Efficiency of combined antibiotic therapy reported in our study excluded the risk for surgical partial lung resection.

Standard immunosuppression following heart transplantation is a calcineurin inhibitor based triple-drug regimen [29]. Monotherapy is limited to rare situations [30]. Mycophenolate and steroids early withdrawal is rare in clinical practice despite good mid-term survival and low rates of allograft rejection and vasculopathy in the TICTAC trial [31]. Kidney recipients can be successfully treated with long-term maintenance immunosuppression monotherapy, especially in case of mycophenolate intolerance [32]. Good results of tacrolimus monotherapy in late postoperative follow-up has been described in retrospective analysis so far [33]. In our case, immunosuppression was limited due to severe fungal infection in the early period (2 months after surgery). Although it was performed 2 months following transplantation, there were no episodes of rejection within the first postoperative year.

\section{Conclusions}

The present case proved the efficiency of combined (voriconazole and caspofungin) antibiotic therapy in invasive pulmonary aspergillosis. Computed tomography findings followed by the serum galactomannan index are useful tools for early diagnosis. Additional modification of the immunosuppressive regimen can be performed safely in early postoperative period in case of severe infection.

\section{Disclosure}

Authors report no conflict of interest.

\section{References}

1. Pacholczyk M, Lagiewska B, Lisik W, Wasiak D, Chmura A. Invasive fungal infections following liver transplantation - risk factors, incidence and outcome. Ann Transplant 2011; 16: 14-16.

2. Silveira FP, Husain S. Fungal infections in solid organ transplantation. Med Mycol 2007; 45: 305-320.

3. García-Ruiz JC, Amutio E, Pontón J. Infección fúngica invasora en pacientes inmunodeficientes. Rev Iberoam Micol 2004; 21: 55-62.

4. McNeil MM, Nash SL, Hajjeh RA, Phelan MA, Conn LA, Plikaytis BD, Warnock DW. Trends in mortality due to invasive mycotic diseases in the United States, 1980-1987. Clin Infect Dis 2001; 33: 641-647.

5. Kontoyiannis DP, Bodey GP. Invasive aspergillosis in 2002: an update. Eur J Clin Microbiol Infect Dis 2002; 21: 161-172.
6. Mucha K, Foroncewicz B, Orłowski T, Religioni J, Bobek-Billewicz B, Jarząb B, Raczyńska J, Krawczyk M, Pączek L. Atypical presentation of invasive pulmonary aspergillosis in a liver transplant recipient. Ann Transplant 2013; 18: 238-242.

7. Perfect JR. Fungal diagnosis: how do we do it and can we do better? Curr Med Res Opin 2013; 29 (Suppl 4): 3-11.

8. Lass-Flörl C, Salzer GM, Schmid T, Rabl W, Ulmer H, Dierichi MP. Pulmonary Aspergillus colonization in humans and its impact on management of critically ill patients. Br J Haematol 1999; 104: 745-747.

9. Hoenigl M, Strenger V, Buzina W. European Organization for the Research and Treatment of Cancer/Mycoses Study Group (EO- RTC/MSG) host factors and invasive fungal infections in patients with haematological malignancies. J Antimicrob Chemother 2012; 67: 2029-2033.

10. Hoenigl M, Zollner-Schwetz I, Sill H, Linkesch W, Lass-Flörl C, Schnedl WJ, Krause R. Epidemiology of invasive fungal infections and rationale for antifungal therapy in patients with haematological malignancies. Mycoses 2011; 54: 454-459.

11. Logan PM, Müller NL. High-resolution computed tomography and pathologic findings in pulmonary aspergillosis: a pictorial essay. Can Assoc Radiol J 1996; 47: 444-452.

12. Park SY, Lim C, Lee SO. Computed tomography findings in invasive pulmonary aspergillosis in non-neutropenic transplant recipients and neutropenic patients, and their prognostic value. J Infect 2011; 63: 447-456.

13. Kuhlman JE, Fishman EK, Siegelman SS. Invasive pulmonary aspergillosis in acute leukemia: characteristic findings on $\mathrm{CT}$, the $\mathrm{CT}$ halo sign, and the role of CT in early diagnosis. Radiology 1985; 157: 611-614.

14. Curtis AM, Smith GJ, Ravin CE. Air crescent sign of invasive aspergillosis. Radiology 1979; 133: 17-21.

15. Maertens J, Verhaegen J, Lagrou K et al. Screening for circulating galactomannan as a noninvasive diagnostic tool for invasive aspergillosis in prolonged neutropenic patients and stem cell transplantation recipients: a prospective validation. Blood 2001; 97: 1604-1610.

16. Gil L, Kozłowska-Skrzypczak M, Czyż A, Lojko-Dankowska A, Nowicki A, Komarnicki M. Diagnostic and treatment strategy of invasive aspergillosis based on galactomannan screenning - prospective analysis of 268 patients after hematopoietic stem cell transplantation. Ann Transplant 2009; 14: 21-22.

17. Meersseman W, Vandecasteele SJ, Wilmer A, Verbeken E, Peetermans WE, Van Wijngaerden E. Invasive aspergillosis in critically ill patients without malignancy. Am J Respir Crit Care Med 2004; 170: 621-625.

18. Mikulska M, Furfaro E, Del Bono V, Raiola AM, Ratto S, Bacigalupo A, Viscoli C. Piperacillin/tazobactam (Tazocin ${ }^{\mathrm{TM}}$ ) seems to be no longer responsible for false-positive results of the galactomannan assay. J Antimicrob Chemother 2012; 67: 1746-1748.

19. Singh N, Limaye AP, Forrest G, Safdar N, Muńoz P, Pursell K, Houston S, Rosso F, Montoya JG, Patton P, Del Busto R, Aguado JM, Fisher RA, Klintmalm GB, Miller R, Wagener MM, Lewis RE, Kontoyiannis DP, Husain S. Combination of voriconazole and caspofungin as primary therapy for invasive aspergillosis in solid organ transplant recipients: a prospective, multicenter, observational study. Transplantation 2006; 81: 320-326.

20. Yeghen T, Kibbler CC, Prentice HG, Berger LA, Wallesby RK, McWhinney PH, Lampe FC, Gillespie S. Management of invasive pulmonary aspergillosis in hematology patients: a review of 87 consecutive cases at a single institution. Clin Infect Dis 2000; 31: 859-868.

21. Groll AH, Shah PM, Mentzel C, Schneider M, Just-Nuebling G, Huebner K. Trends in the postmortem epidemiology of invasive fungal infections at a university hospital. J Infect 1996; 33: 23-32.

22. Ruhnke M, Böhme A, Buchheidt D, Cornely O, Donhuijsen K, Einsele H, Enzensberger R, Hebart H, Heussel CP, Horger M, Hof H, Karthaus M, Krüger W, Maschmeyer G, Penack O, Ritter J, Schwartz S; Infectious Diseases Working Party in Haematology and Oncology of the German Society for Haematology and Oncology. Diagnosis of invasive fungal infections in hematology and oncology-guidelines of the infectious diseases working party (AGIHO) of the German society of Hematology and Oncology (DGHO). Ann Hematol 2003; 82 (Suppl. 2): 141-148.

23. Meersseman W, Lagrou K, Maertens J, Wilmer A, Hermans G, Vanderschueren S, Spriet I, Verbeken E, Van Wijngaerden E. Galactomannan in bronchoalveolar lavage fluid: a tool for diagnosing aspergillosis in intensive care unit patients. Am J Respir Crit Care Med 2008; 177: 27-34.

24. Bernard A, Caillot D, Couaillier JF, Casasnovas O, Guy H, Favre JP. Surgical management of invasive pulmonary aspergillosis in neutropenic patients. Ann Thorac Surg 1997; 64: 1441-1447. 
25. Gossot D, Validire P, Vaillancourt R, Socié G, Esperou H, Devergie A, Guardiola P, Grunenwald D, Gluckman E, Ribaud P. Full thoracoscopic approach for surgical management of invasive pulmonary aspergillosis. Ann Thorac Surg 2002; 73: 240-244.

26. Gow KW, Hayes-Jordan AA, Billups CA, Shenep JL, Hoffer FA, Davidoff AM, Rao BN, Schropp KP, Shochat SJ. Benefit of surgical resection of invasive pulmonary aspergillosis in pediatric patients undergoing treatment for malignancies and immunodeficiency syndromes. J Pediatr Surg 2003; 38: 13541360 .

27. Kaffarnik M, Utzolino S, Blaich A, Hopt UT. Successful multimodal therapy of invasive pulmonary and central nervous system aspergillosis in a neutropenic surgical patient: case report and review of the literature. Mycoses 2008; 51: 74-78.

28. Pidhorecky I, Urschel J, Anderson T. Resection of invasive pulmonary aspergillosis in immunocompromised patients. Ann Surg Oncol 2000; 7: 312-317.

29. Urbanowicz T, Baszyńska-Wachowiak H, Ligowski M, Straburzyńska-Migaj E, Misterski M, Jemielity M. Comparison of conventional tacrolimus versus pro- long release formula as initial therapy in heart transplantation. Ann Transplant 2014; 19: 295-299.

30. Lee CM, Lee YT, Jeng LB, Chang CY, Wei J. Monotherapy with tacrolimus for heart and liver transplant: a case report. Transplant Proc 2014; 46: 980-981.

31. Baran DA, Zucker MJ, Arroyo LH, Camacho M, Goldschmidt ME, Nicholls SJ, Prevost-Fernandez J, Carr C, Adams L, Pardi S, Hou V, Binetti M, McCahill J, Chichetti J, Viloria V, Sanagustin MG, Ebuenga-Smith J, Mele L, Martin A, Blicharz D, Wolski K, Olesnicky L, Qian F, Gass AL, Cohen M. A prospective, randomized trial of single-drug versus dual-drug immunosuppression in heart transplantation: the tacrolimus in combination, tacrolimus alone compared (TICTAC) trial. Circ Heart Fail 2011; 4: 129-137.

32. Augusto JF, Subra JF, Onno C, Villemain F, Croue A, Dussaussoy C, Picquet J, Coeffic B, Sayegh J. Long-term maintenance immunosuppressive regimen with tacrolimus monotherapy. Ann Transplant 2013; 18: 368-377.

33. Lubitz SA, Baran DA, Alwarshetty MM, Pinney S, Kaplan S, Chan M, Courtney MC, Lansman SL, Spielvogel D, Gass AL Long-term results of tacrolimus monotherapy in cardiac transplant recipients. J Heart Lung Transplant 2006; 25: 699-706. 